\title{
Decline of native bees (Apidae: Euglossa) in a tropical forest of Panama
}

\author{
Álvaro Vega-Hidalgo ${ }^{1}$ (D), Yostin AÑIno ${ }^{2,3}$, Erin Krichilsky ${ }^{4}$, Adam R. SMith ${ }^{5}$, \\ Alonso SANTOS-Murgas ${ }^{2}$, Dumas GÁlvez ${ }^{6,7}$ \\ ${ }^{1}$ Escuela de Ciencias Biológicas, Universidad Nacional de Costa Rica, Heredia, Costa Rica \\ ${ }^{2}$ Museo de Invertebrados G.B. Fairchild, Universidad de Panamá, Panamá, Panama \\ ${ }^{3}$ Programa de Maestría en Gestión Ambiental y Sostenibilidad, Universidad del Istmo, Panamá, Panama \\ ${ }^{4}$ Department of Entomology, Cornell University, Ithaca, USA \\ ${ }^{5}$ Department of Biological Sciences, George Washington University, Washington DC, USA \\ ${ }^{6}$ Programa Centroamericano de Maestría en Entomología, Panamá Universidad de Panamá, Estafeta Universitaria, \\ Avenida Simón Bolívar, 0824, Panama, Panama \\ ${ }^{7}$ COIBA AIP, Panama, Panama
}

Received 19 December 2019 - Revised 25 May 2020 - Accepted 5 June 2020

\begin{abstract}
We measured abundance, diversity, and richness of Euglossa bees (Euglossini, Apidae) in lowland semi-deciduous forest in Darién National Park, Panamá, during the wet and dry seasons in the canopy and understory for five consecutive years (2013 to 2017) using McPhail traps baited with eucalyptus oil. We found a precipitous decline in abundance and richness throughout the 5 years of our study. Alpha diversity also declined throughout the study. Abundance, species richness and alpha diversity were significantly higher in the dry than in the wet season. There were no significant differences in the diversity, richness, or abundance between the canopy and understory. Our data contrast sharply with previous long-term studies of euglossine bees which showed stable populations.
\end{abstract}

\section{abundance / insect decline / species richness / tropical forest / pollinator}

\section{INTRODUCTION}

Several recent studies have demonstrated widespread declines in bee populations (Biesmeijer et al. 2006; Kosior et al. 2007; Colla and Packer 2008; Frankie et al. 2009; Winfree et al. 2009; Brown and Paxton 2009; Potts et al. 2010; Ollerton et al. 2011; Burkle et al. 2013; Senapathi

Electronic supplementary material The online version of this article (https://doi.org/10.1007/s13592-020-00781-2) contains supplementary material, which is available to authorized users.

Corresponding author: D. Gálvez, dumas.galvezs@up. ac.pa

Manuscript editor: Cedric Alaux et al. 2015; Goulson et al. 2015; Koh et al. 2016; Ollerton 2017; Sánchez-Bayo and Wyckhuys 2019). These declines are typically associated with anthropogenic disturbances such as habitat loss or pesticide use. The prominent role of anthropogenic disturbance in bee population declines suggests that bees in undisturbed areas may fare better. Some studies of bee populations in protected or otherwise stable areas show relatively stable populations (e.g., Frankie et al. 1998; Roubik and Wolda 2001; Roubik 2001; Roubik and Villanueva-Gutiérrez 2009; Archer 2013; Herrera 2019). This suggests that long-term survey work in intact, protected habitats is thus important for documenting the fauna in those regions and also monitoring changes over time 
independent of anthropogenic influences (Meiners et al. 2019).

Here, we investigate population trends in abundance, richness, and diversity over 5 years (20132017) of the largest genus of Euglossine bees in the Neotropics, Euglossa (Roubik and Hanson 2004), in a primary forest in Darién National Park, Panama. Euglossine bees (Euglossini, Apidae), commonly known orchid bees, are a diverse tribe with more than 230 currently recognized species and are found only in the Neotropics (Nemésio and Rasmussen 2011). Their common name comes from the remarkable behavior of the males, which collect scents that they use to attract females during courtship (Eltz et al. 1999, 2005). Many orchids produce scents attractive to the males so that the males pollinate the orchids while collecting scents (Dressler 1982). However not all species pollinate orchids, and the importance of euglossines extends beyond orchids, as these bees also visit other plants in search of nectar, pollen, fragrances, and resins (Roubik and Hanson 2004; Borrell 2005; Pemberton and Wheeler 2006; López-Uribe et al. 2008). One consequence of the males' attraction to scents is that euglossine bee abundance and diversity can be sampled using chemical baits that attract male bees (e.g., Ackerman 1983; Pearson and Dressler 1985; Roubik and Ackerman 1987; Powell and Powell 1987; Oliveira and Campos 1995; Peruquetti et al. 1999; Roubik 2001, 2004; Nemésio 2013; Nemésio et al. 2015; Ramírez et al. 2015).

Despite the utility of scent baiting for population monitoring of euglossine bees, most studies of community ecology only collect data for a single season or across seasons for a single year (e.g., Ackerman 1983; Powell and Powell 1987; Oliveira and Campos 1995; Ramírez et al. 2015; Botsch et al. 2017). There are few studies of population dynamics and community composition over multiple years. Roubik (2001) presents data from 21 years of monitoring the euglossine bee fauna of central Panamá (Roubik 2001), and Nemésio et al. (2015) monitored euglossine bees over 14 years in an urban remnant of Atlantic forest in Belo Horizonte, Brazil. The studies of Roubik (2001) and Nemésio et al. (2015) show remarkable stability in abundance and community composition over the long term, despite fluctuations in population at both the species and community level from year to year.
Peruquetti et al. (1999) also monitored euglossine bees for three consecutive years in the Atlantic forest of Brazil, and Pearson and Dressler (1985) sampled bees for 2 years in southeastern Peru; neither study found clear abundance trends. Nemésio (2013) returned to a previously sampled site 12 years later to document the effects of deforestation since the original sample, finding that forest-dependent species declined but species associated with open habitat became more common.

In our study, we used scent traps to measure abundance, richness, and diversity of Euglossa in both the understory and canopy levels, because forest stratification (height) can generate differences in insect communities (Roubik 1993; Schulze et al. 2001; Stangler et al. 2016). Trends for orchid bees are unclear; some studies found higher abundance in the canopy (Ferreira et al. 2011) and higher richness in the understory (Martins and Souza 2005). Nevertheless, we predicted that at least abundance would be higher in the understory, which is a more recurrent trend observed for other orchid bees' communities (e.g., Roubik 1993; Otero and Sallenave 2003, Vilhena et al. 2017). We also sampled in both the wet and dry seasons, as seasonality can affect orchid bee abundance and diversity (Ackerman 1983; Pearson and Dressler 1985; Ramírez et al. 2015; RochaFilho and Garófalo 2014). We predicted that abundance and species richness would be higher in the dry than in the wet season, based off previous studies in central Panamá (Ackerman 1983; Roubik 2001). Because Darién National Park is a primary forest protected from anthropogenic disturbances, we predicted population stability over the 5 years of our study. This is the first long-term study of euglossines in Parque Nacional Darién (PND) to sample both wet and dry seasons and canopy and understory, and one of the few long-term studies of euglossine populations anywhere.

\section{MATERIALS AND METHODS}

\subsection{Study site}

PND is a world heritage site (UNESCO 1981) and the largest park in Panamá $\left(5790 \mathrm{~km}^{2}\right)$, covering $90 \%$ of the Panamá-Colombia border. We conducted this study at Rancho Frio Biological Station (8.017834, - 77.732739), which is in a semi- 
deciduous lowland forest with a pronounced dry season from December to April (Santos-Murgas et al. 2018).

Weather data are not available for Rancho Frio, but we were able to access rainfall data from the Empresa de Transmisión Eléctrica (ETESA) weather station at Camoganti, $20 \mathrm{~km}$ NW of Rancho Frio (http://www.hidromet.com.pa/clima historicos.php). No temperature or other data were available for this station. We calculated average daily rainfall for each month from 1980 to 2012 , as well as average daily rainfall for each month of our study, until October 2016, since after this date, no weather data were available. To test if rainfall patterns during our study differed from the previous 32 years, we compared monthly rainfall before and during our study using a $t$ test.

\subsection{Collections}

We monitored Euglossa bees for 5 years, from 2013 to 2017, by trapping for six continuous days during both the dry season (December-April) and the wet season (May-November) of each year. We made 12 collections on the following dates: April, December (both dry season), and August (wet season) of 2013; April (dry), July, and November (wet) of 2014; April (dry) and November (wet) of 2015; March (dry) and October (wet) of 2016; and March (dry) and August (wet) of 2017. We used McPhail traps baited with concentrated eucalyptus oil (Bennett 1972; Powell and Powell 1987). We placed six traps per forest stratum (six understory at $1.5 \mathrm{~m}$ and six canopy at $20-25 \mathrm{~m}$ from the ground) for a total of 12 traps. The $12 \mathrm{McPhail}$ traps were distributed in two locations separated by $2 \mathrm{~km}$ from each other. At each location, three trees, each separated by approximately $50 \mathrm{~m}$ along the trail, were used as trap locations (one trap per stratum). This results in two groups of three trees, in which each tree contained a single understory and single canopy trap. We used the same trap locations every year. All samples from each stratum (canopy or understory) for each collecting event were pooled upon collection, for a total of 24 samples (12 collections of bees from the canopy and 12 collections from the understory). We preserved all collected bees in $70 \% \mathrm{EtOH}$ and deposited them at the GB Fairchild Invertebrate Museum at the University of
Panamá (MIUP), where we identified species following the key of Roubik and Hanson (2004).

\subsection{Alpha and beta diversity analysis}

We calculated alpha diversity indices for each stratum (canopy and understory): richness, abundance, Simpson diversity (1-D), Shannon diversity $(\mathrm{H})$, and Fisher's alpha. We used a generalized linear model (GZLM) with a normal distribution with season (wet or dry) and strata (canopy or understory) as factors and date as a covariate to compare alpha diversity indices. We also calculated beta diversity indices (dissimilarity indices) to compare between canopy and understory and to compare between seasons. We calculated Jaccard $\left(\mathrm{S}_{\mathrm{j}}\right)$, Morisita $\left(\mathrm{S}_{\mathrm{m}}\right)$, and Bray-Curtis $\left(\mathrm{S}_{\mathrm{b}}\right)$ dissimilarity indices (Magurran 2004). To compare dissimilarity indices between canopy and understory, we calculated them for each collection. We compared dissimilarity indices across seasons by comparing two consecutive collection dates from the same stratum within each season (e.g., canopy from April 2013 and canopy from August 2013). We compared seasonal dissimilarity indices with canopy stratum dissimilarity indices with a $t$ test. All diversity indices were calculated in R (R Core Team 2019).

\subsection{Statistical tests of abundance and richness}

To test our hypotheses of bee abundance at the population level, we used a GZLM with a negative binomial distribution, because the data were counts with high variance and many zeros. We included stratum (canopy or understory), season (dry or wet), and species identity as factors to test our hypotheses for stratum and seasonal differences and to account for the large variation in abundances between species (see "Results" below and Figure 1). We also included collection date as a covariate to test for a change in abundance over time. We did not include trap location as a random factor because all traps for each stratum (canopy or understory) were pooled upon collection.

We recorded species richness as the total number of species in each sample. We did not estimate population richness from our samples. We also used a GZLM to analyze richness, but with a 


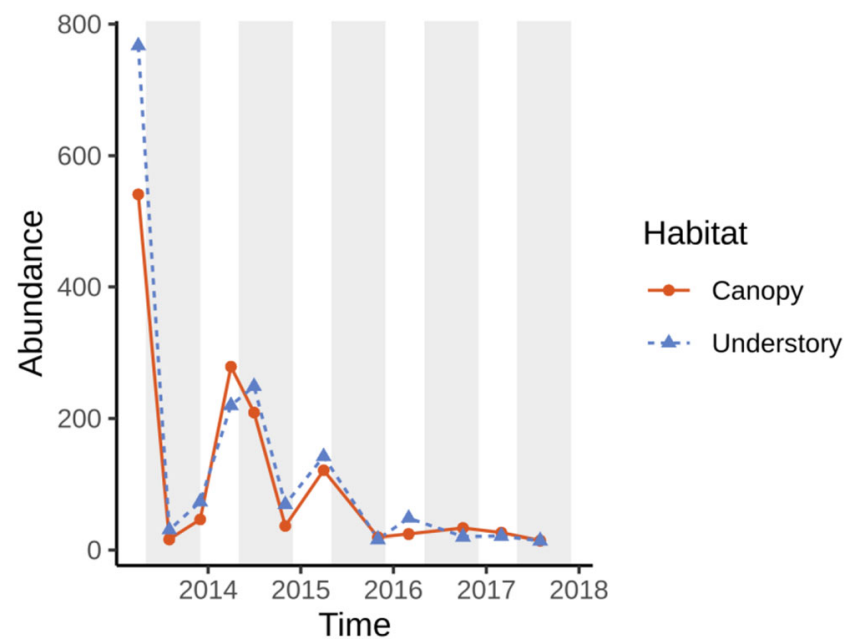

Figure 1. Number of individuals collected in the canopy (solid orange lines and circles) and understory (dashed blue lines and triangles) at each collection. The gray and white areas represent the wet and dry seasons, respectively.

normal distribution because richness values were normally distributed. All GZLMs were performed in SPSS (version 25).

\section{RESULTS}

\subsection{Abundance and diversity}

We collected 3038 Euglossa bees during the study period, representing 28 species (Table I). Two species, Euglossa imperialis and Euglossa tridentata, accounted for nearly half $(48.76 \%)$ of the collected individuals. The five most abundant species accounted for $75.47 \%$ of all individuals, and the 17 most abundant species accounted for $98.09 \%$ of all individuals, with the 11 least common species accounting for less than $2 \%$ of all collected individuals (Table I). The only species collected in all 24 samples was E. imperialis (Table I), which was the most abundant species (rank $=1$ ) in 14 of the 24 samples (average abundance rank $=1.63 \pm 0.88 \mathrm{SD})$.

\subsection{Population decline}

Both abundance and species richness declined over time. A GZLM of abundance showed a significant effect of season, species identity, and date, but not stratum (season LR $\chi^{2}=40.34, \mathrm{df}=1$, $p<0.001$; species LR $\chi^{2}=1058.65$, $\mathrm{df}=27$, $p<0.001$; date LR $\chi^{2}=241.12, \mathrm{df}=1, p<0.001$; stratum LR $\chi^{2}=0.21, \mathrm{df}=1, p=0.64$; Figure 1).

Species richness also declined over time and showed an effect of season but no effect of stratum (season LR $\chi^{2}=8.58, \mathrm{df}=1, p=0.002$; stratum LR $\chi^{2}=0.08, \mathrm{df}=1, p=0.77$; date LR $\chi^{2}=$ $9.05, \mathrm{df}=1, p=0.003$; Figure 2). There was a correlation between abundance and species richness across collections $(N=24$ collections, Spearman's rho $=0.88, p<0.001)$.

Different species showed different patterns of abundance over time (Figure 3). Some of these declined from the beginning of the study to the end (such as E. tridentata and Euglossa hansoni), while others showed an increase after the first year of the study, followed by an eventual decline (such as Euglossa ignita and Euglossa deceptrix; Figure 3). Other species either showed irregular patterns or had small sample sizes; no species showed evidence of increase over time (Figure 3 ).

There were no dramatic changes in rainfall that correlated with declines in bee abundance (Figure 4). The wet season of 2013 was quite wet, and the 2015 wet season and following 2016 dry season were both relatively dry, consistent with the 2015-2016 El Niño seasonal oscillation in central Panama (Bretfeld et al. 2018). There was no difference in monthly rainfall during the years of our study compared with the 32 years before $\left(t_{431}=0.28, p=0.78\right)$. 
Table I. List of Euglossa species collected, in descending order of abundance rank. Asterisks (*) indicate tied rank. Occurrence lists the number of collections (out of 24 possible) in which each species was collected

\begin{tabular}{|c|c|c|c|c|c|}
\hline Rank & Species & Number collected & Percent of total & Cumulative percent & Occurrence \\
\hline 1 & Euglossa imperialis & 786 & 25.91 & 25.91 & 24 \\
\hline 2 & Euglossa tridentata & 693 & 22.85 & 48.76 & 20 \\
\hline 3 & Euglossa hansoni & 294 & 9.69 & 58.46 & 15 \\
\hline 4 & Euglossa deceptrix & 281 & 9.26 & 67.72 & 15 \\
\hline 5 & Euglossa variabilis & 235 & 7.75 & 75.47 & 13 \\
\hline 6 & Euglossa despecta & 121 & 3.99 & 79.46 & 9 \\
\hline 7 & Euglossa ignita & 105 & 3.46 & 82.92 & 14 \\
\hline 8 & Euglossa flammea & 99 & 3.26 & 86.19 & 6 \\
\hline 9 & Euglossa gorgonensis & 73 & 2.41 & 88.59 & 15 \\
\hline 10 & Euglossa bursigera & 67 & 2.21 & 90.80 & 12 \\
\hline 11 & Euglossa sapphirina & 44 & 1.45 & 92.25 & 9 \\
\hline$* 12$ & Euglossa cyanaspis & 36 & 1.19 & 93.44 & 1 \\
\hline$* 12$ & Euglossa heterosticta & 36 & 1.19 & 94.63 & 12 \\
\hline 14 & Euglossa dissimula & 30 & 0.99 & 95.61 & 7 \\
\hline 15 & Euglossa dodsoni & 27 & 0.89 & 96.51 & 6 \\
\hline 16 & Euglossa allosticta & 26 & 0.86 & 97.36 & 8 \\
\hline 17 & Euglossa igniventris & 22 & 0.73 & 98.09 & 1 \\
\hline$œ 18$ & Euglossa asarophora & 13 & 0.43 & 98.52 & 5 \\
\hline 19 & Euglossa mixta & 12 & 0.40 & 98.91 & 2 \\
\hline 20 & Euglossa crassipunctata & 9 & 0.30 & 99.21 & 4 \\
\hline 21 & Euglossa dressleri & 8 & 0.26 & 99.47 & 4 \\
\hline 22 & Euglossa championi & 7 & 0.23 & 99.70 & 4 \\
\hline 23 & Euglossa turbinifex & 3 & 0.10 & 99.80 & 2 \\
\hline 24 & Euglossa cognata & 2 & 0.07 & 99.87 & 2 \\
\hline$* 25$ & Euglossa hemichlora & 1 & 0.03 & 99.90 & 1 \\
\hline$* 25$ & Euglossa hyacinthina & 1 & 0.03 & 99.93 & 1 \\
\hline$* 25$ & Euglossa $\mathrm{sp}$ & 1 & 0.03 & 99.97 & 1 \\
\hline \multirow[t]{2}{*}{$* 25$} & Euglossa $\mathrm{sp} 1$ & 1 & 0.03 & 100.00 & 1 \\
\hline & Total & 3033 & & & \\
\hline
\end{tabular}

\subsection{Effects of season and habitat}

Bee abundance was higher in the dry season (see GZLM results above, Figures 1 and 3). Species richness was significantly higher in the dry season (see GZLM results above; dry season average $\pm \mathrm{SD}=11.17 \pm 3.97$, range $=5-18$, wet season $=6.67 \pm 3.11$, range $=3-13$; Figure 3).

Alpha diversity, as measured by the Shannon and Simpson, but not Fisher, indices were significantly higher in the dry than in the wet season (Table II, Figure 5). None of the diversity indices differed between the canopy and understory, and the Shannon, but not the Fisher or Simpson, diversity index declined significantly over the course of the study (Table II, Figure 5).

There was no effect of stratum (canopy or understory) on species richness (see GZLMs above; canopy $=9.08 \pm 4.74$, range $=3-18$, understory $=$ $8.75 \pm 3.74$, range $=3-14$; Figure 2). There was 


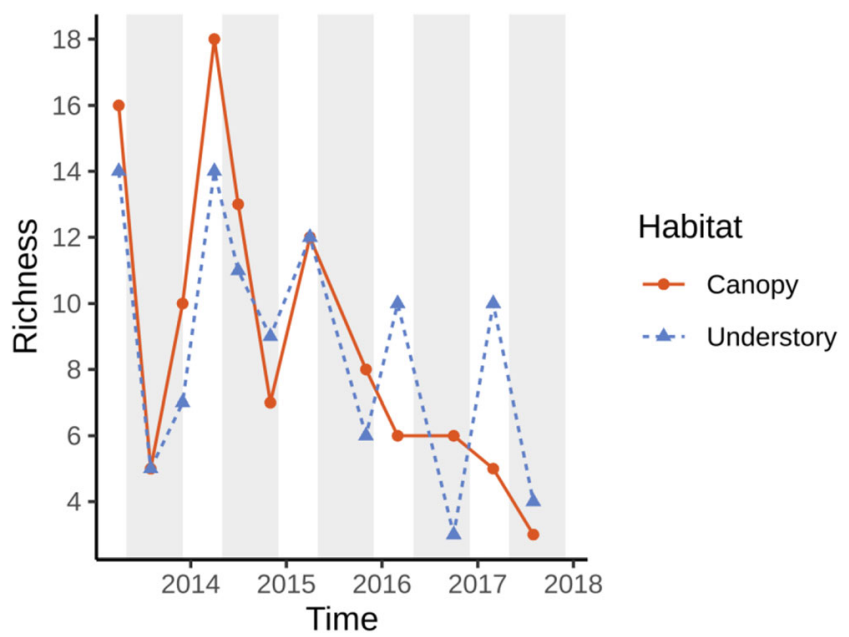

Figure 2. Species richness at each collection for canopy (solid orange lines and circles) and understory (dashed blue lines and triangles). The gray and white areas represent the wet and dry seasons, respectively.

also no effect of stratum on bee abundance, either at the total or individual species level (see GZLM above, Figure 1).

The dissimilarity diversity indexes showed low dissimilarity values between canopy and understory collections made at the same time (Table III). In contrast, the dissimilarity values between a given collection and the previous collection made at the same stratum (either canopy or understory) were significantly higher than the canopy-understory values (Morisita $t_{21,11}=3.54$, $p=0.001$; Jaccard $t_{21,11}=5.95, p<0.001$; BrayCurtis $t_{21,11}=5.84, p<0.001$; Table III). These comparisons include 10 dry to wet season transitions, eight wet to dry season transitions, and four wet season collections following another wet season collection (Table III). The wet-to-subsequent dry season comparisons were less dissimilar than were the dry-to-subsequent wet season comparisons, although this difference was statistically significant only for the Bray-Curtis index (Morisita $t_{7,9}=1.63, p=0.12$; Jaccard $t_{7,9}=1.86, p=$ 0.08; Bray-Curtis $t_{7,9}=2.29, p=0.04$; Table III)

\section{DISCUSSION}

\subsection{Population decline}

We found evidence that abundance and species richness of Euglossa bees declined during the 5 years of the study. This trend was consistent for both the understory and canopy. Our results are in line with the long-term declines in richness and abundance of native bees from other parts of the world (Biesmeijer et al. 2006; Winfree et al. 2009; Bommarco et al. 2012; Brown and Paxton 2009; Burkle et al. 2013; Colla and Packer 2008; Frankie et al. 2009; Goulson et al. 2015; Senapathi et al. 2015; Grixti et al. 2008; Koh et al. 2016; Kosior et al. 2007; Ollerton 2017; Ollerton et al. 2011; Potts et al. 2010; SánchezBayo and Wyckhuys 2019). In these studies, some of the main drivers of decline are agriculture intensification, urbanization, and pesticide use. In fact, some of the few long-term studies that did not find steep declines in bee populations were those conducted in areas protected from these anthropogenic drivers (Frankie et al. 1998; Roubik and Wolda 2001; Roubik 2001; Roubik and Villanueva-Gutiérrez 2009; Archer 2013; Herrera 2019 but see Hallmann et al. 2017; Rada et al. 2019). Since our study site was located within a primary forest in a national park, it seems likely that none of the typical anthropogenic drivers of bee decline caused the dramatic population decline shown in our results.

Further work is needed to elucidate the mechanisms behind our results. Rainfall during the period of our study did not differ from rainfall during the previous 32 years. However, changes in others climatic parameters, like temperature, may have contributed to the observed bee decline 

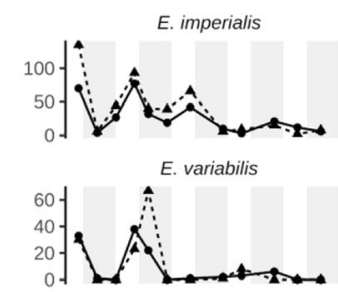

E. gorgonensis
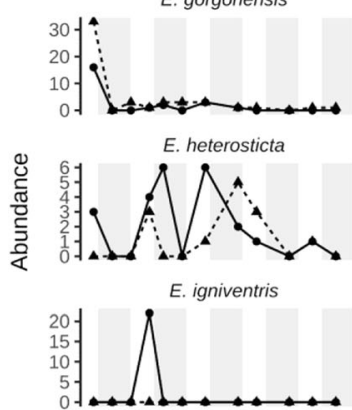

E. dressleri

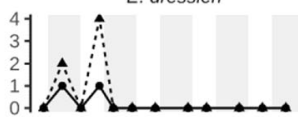

E. hemichlora

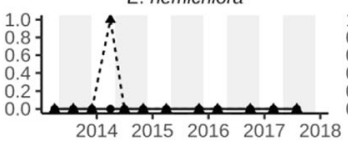

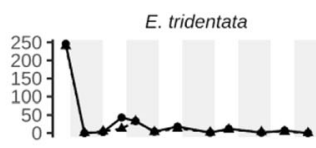

E. despecta

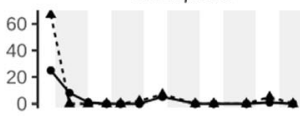

E. bursigera

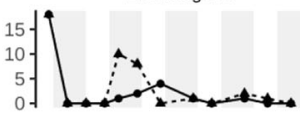

E. dissimula

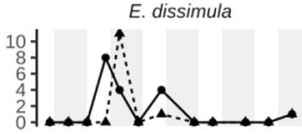

E. asarophora

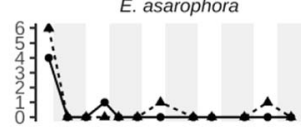

E. championi

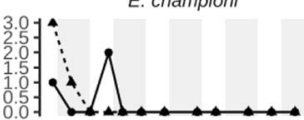

E. hyacinthina

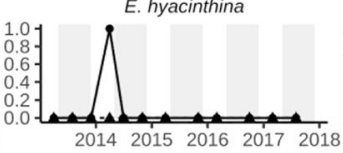

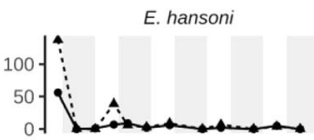

E. ignita

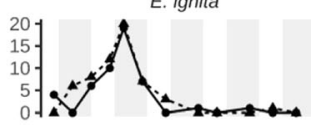

E. sapphirina

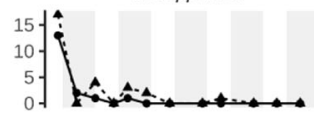

E. dodsoni

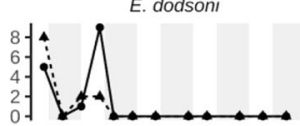

E. mixta

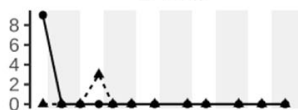

E. turbinifex

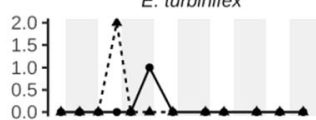

E. sp

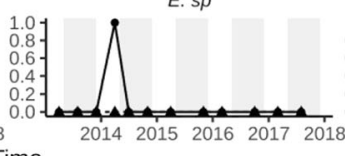

Time

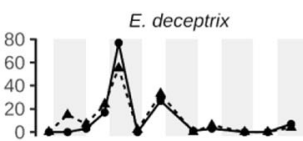

E. flammea

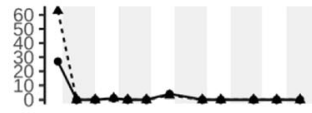

E. cyanaspis

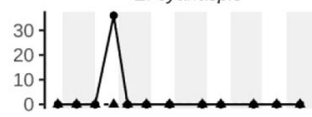

E. allosticta

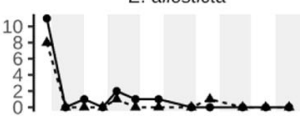

E. crassipunctata

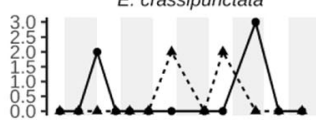

E. cognata

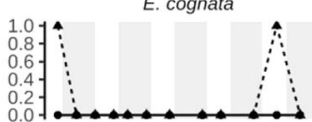

E. $\mathrm{sp} 1$

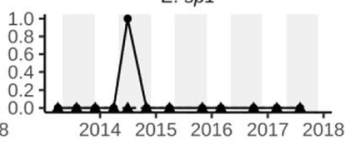

Figure 3. Abundance over time of all Euglossa species in the study, ordered by overall abundance. Note that the vertical axes are different scales for each panel. The gray and white areas represent the wet and dry seasons, respectively. Solid lines with circles represent canopy collections, while dashed lines with triangles represent understory collections.

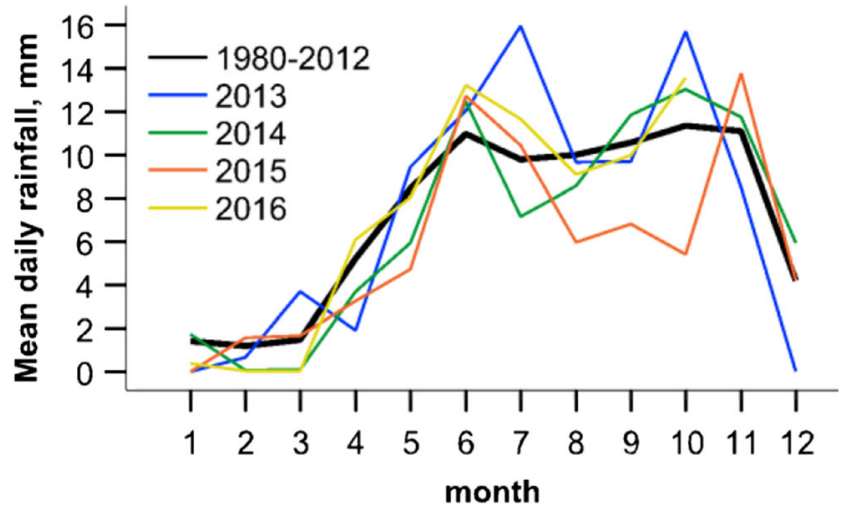

Figure 4. Seasonal rainfall during our study. The black line represents mean daily rainfall by month (January $=1$, December $=12$ ) for the 32 years prior to our study at Camogantí, $20 \mathrm{~km} \mathrm{NW}$ of Rancho Frio. Mean daily rainfall for each month of our study until October 2016 is shown by year (blue for 2013, green for 2014, orange for 2015, yellow for 2016). No data are available after October 2016. 
Table II. GZLM results for measures of alpha diversity. Mean values \pm SD are listed for each diversity index by season and by strata. The likelihood ratio chi-square and $p$ values for each term in the GZLM are presented for each factor (season and strata, $\mathrm{df}=1$ for each comparison) and for the date covariate

\begin{tabular}{|c|c|c|c|c|c|c|c|c|c|c|}
\hline & \multirow[b]{2}{*}{ Dry season } & \multirow[b]{2}{*}{ Wet season } & \multicolumn{2}{|c|}{ Season } & \multirow[b]{2}{*}{ Canopy } & \multirow[b]{2}{*}{ Understory } & \multicolumn{2}{|c|}{ Strata } & \multicolumn{2}{|c|}{ Date } \\
\hline & & & $\begin{array}{l}\text { LR } \\
\chi^{2}\end{array}$ & $\mathrm{p}$ & & & $\begin{array}{l}\text { LR } \\
\chi^{2}\end{array}$ & $p$ & $\begin{array}{l}\text { LR } \\
\chi^{2}\end{array}$ & $p$ \\
\hline Shannon & $1.76 \pm 0.31$ & $1.35 \pm 0.37$ & 7.34 & 0.01 & $1.54 \pm 0.38$ & $1.58 \pm 0.42$ & 0.09 & 0.76 & 4.29 & 0.04 \\
\hline Simpson & $0.75 \pm 0.09$ & $0.65 \pm 0.11$ & 4.97 & 0.03 & $0.69 \pm 0.09$ & $0.7 \pm 0.13$ & 0.09 & 0.76 & 2.12 & 0.15 \\
\hline Fisher & $3.43 \pm 1.49$ & $2.49 \pm 1.13$ & 3.28 & 0.07 & $2.98 \pm 1.11$ & $2.94 \pm 1.65$ & 0.01 & 0.94 & 0.15 & 0.70 \\
\hline
\end{tabular}

(Soroye et al. 2020). Mechanisms may also include changes in plant phenology (MillerStruttmann et al. 2015; Pyke et al. 2016), reduction of suitable habitat (Giannini et al. 2012; Valtuille-Faleiro et al. 2018) and floral resources (Roubik and Villanueva-Gutiérrez 2009), or reduced genetic variation (Packer and Owen 2001). Competition with or pathogen transmission from honeybees (Fürst et al. 2014) may affect population, although Roubik (2001) showed that competition with invasive honeybees did not affect orchid bee populations in central Panama.

Our results also highlight the fact that bee populations can decline even in areas protected from anthropogenic disturbance (Hallmann et al. 2017; Rada et al. 2019). Our study was designed to compare community composition between the canopy and understory. We did not set out to monitor population decline, so we did not monitor surrounding areas to the study site for comparison. However, a parallel study to this one by SantosMurgas et al. (2018) shows that abundance and richness did not differ between the border and interior of the forest. Still, it remains unknown whether perturbation of surrounding habitats influence orchid bee communities or other insects inhabiting the reserve interior, as seen for other taxa (Laurance et al. 2012). Altogether, our results

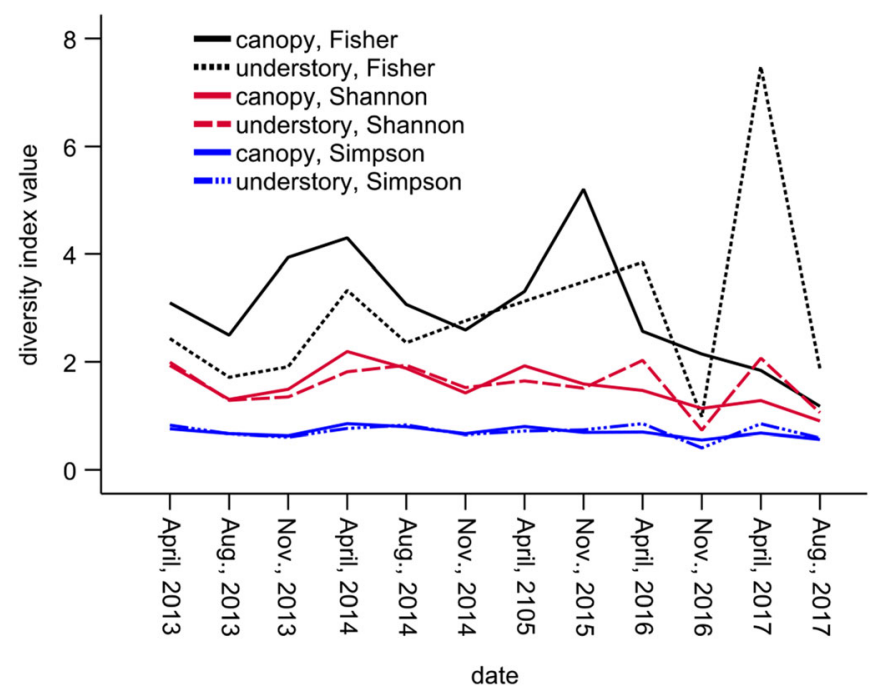

Figure 5. Diversity indices for each collection in our study. Collection dates are on the $X$-axis, and diversity index values are plotted on the $Y$-axis. Fisher's index is in black, Shannon in red, and Simpson in blue. Solid lines indicate canopy collections, and dashed lines indicate understory collections. 
suggest that fragmentation and habitat loss are not required for orchid bee populations to decline, despite the importance of these factors for other orchid bee communities (Nemésio 2013; Nemésio et al. 2016; Storck-Tonon and Peres 2017) and native bees in general (Goulson et al. 2015; Koh et al. 2016; Ollerton et al. 2014).

Furthermore, the mechanisms driving the declines seem to be equally affecting both rare and common species. Research is still needed to understand basic aspects of the biology of orchid bees in order to comprehend how these declines are driven (Añino et al. 2019). Monitoring of orchid bees in the city of Belo Horizonte in Brazil (Nemésio et al. 2015) and in central Panamá (Roubik 2001; Roubik and Ackerman 1987) showed long-term stability, despite year-to-year variation in abundance, which contrasts sharply with our data.

The species we collected in our study varied in abundance by almost three orders of magnitude (Table I) and showed different patterns of decline (Figure 3), accounting for the strong effect of species identity in our analysis of abundance, but no species showed an increase in abundance over the 5 years of the study. We believe that the declines we report are not the result of our sampling, given that phenology of orchid bees varies between species (Margatto et al. 2019) and trends in abundance vary between species in our study (Figure 3). Roubik (2001) suggests that at least 4 years of data are necessary to distinguish long-term population trends from year-to-year variation. While our study meets this threshold, future monitoring is required in order to confirm that the trends in abundance and species richness that we document are not the result of large fluctuations in otherwise stable populations (Archer 2013; Frankie et al.1998; Roubik and Villanueva-Gutiérrez 2009; Williams et al. 2001).

\subsection{Influence of season and canopy stratum}

Our data show increased abundance, species richness, and diversity, in the dry season relative to the wet season (see peaks in Figures 1 and 2, and Table II). The effect of seasonality on floral resources in the park is unknown, but in central Panama, the dry season is the peak of floral resource availability (Wright and Calderon 1995). However, this difference may also arise due to the 
lower activity of bees during rainy days in the wet season. In addition, we did not find consistent differences in abundance, diversity, or community composition between the canopy and understory, similar to other studies (e.g., Martins and Souza 2005 for abundance and diversity; Ferreira et al. 2011 for diversity and with a high similarity index). Variation from season to season was consistently greater than within-season variation between canopy and understory (Table III). Most importantly, our data demonstrating declines in abundance and richness were consistent for both strata despite the abiotic differences between them, such as temperature and humidity (Shuttleworth et al. 1984).

\section{CONCLUSION}

Our data suggest dramatic population decline of an important group of Neotropical pollinators, orchid bees, with no ecological explanation that we could identify. We hope that this decline is neither irreversible nor widespread, but the lack of monitoring of bee populations in the Neotropics or native bees in other tropical regions makes it difficult to compare with any other site except central Panama (Roubik 2001). While a thorough sampling of all species in a euglossine community is a time-consuming task, rapid sampling of just a few days provides a reliable estimate of diversity and abundance (Roubik 2004). Programs of rapid sampling sustained over the long term at several sites would provide broader data about euglossine population trends. More long-term monitoring studies are needed in the tropics aimed at elucidating the mechanisms driving population dynamics.

\section{ACKNOWLEDGMENTS}

We thank all the staff of the PND (Mi Ambiente) for the management of collection and lodging permits in the Rancho Frío Biological Station. We thank Steve Paton for helping us obtain the ETESA rainfall data.

\section{AUTHORS' CONTRIBUTIONS}

Insect collection and identification by ASM and YJA. Data analysis by YJA, AVH, and ASM. Manuscript drafting by AVH, YJA, and DG. Correction of the manuscript by ASM, EAK, DG, and AVH. All authors read and approved the final manuscript.

\section{FUNDING INFORMATION}

We thank the Colegio de Biólogos de Panamá (COBIOPA) and the Group for Education and Sustainable Environmental Management (GEMAS) (2014-2017) for the execution of the project in the Darién National Park.

\section{COMPLIANCE WITH ETHICAL STANDARDS}

Conflict of interest The authors declare that they have no competing interests.

Déclin des abeilles indigènes (Apidae: Euglossa) dans une forêt tropicale du Panama.

abondance / déclin des insectes / pollinisateur / richesse des espèces / forêt tropicale

Rückgang von einheimischen Bienen (Apidae: Euglossa) in einem tropischen Regenwald in Panama.

Abundanz / Insektenrückgang / Bestäuber / Artenreichtum / tropischer Regenwald

\section{REFERENCES}

Ackerman, J. (1983) Specificity and mutual dependency of the orchid-euglossine bee interaction. Biol. J. Linn. Soc. 20 (3), 301-314.

Añino, Y., Parra, A., Gálvez, D. (2019) Are orchid bees (Apidae: Euglossini) good indicators of the state of conservation of Neotropical forests? Sociobiology 66 (1), 194-197.

Archer, M.E. (2013) The solitary wasps and bees of a suburban garden in Leicester, England, over 27 years. Entomol. Mon. Mag. 149 (1948), 93-121. 
Bennett, F. (1972) Baited McPhail fruitfly traps to collect euglossine bees. J. New York Entomol. Soc. 80 (3), 137-145.

Biesmeijer, J., Roberts, S., Reemer, M., Ohlemuller, R., Edwards, M., Peeters, T., Schaffers, A., Potts, S., Kleukers, R., Thomas, C., Settele, J., Kunin, W. (2006) Parallel declines in pollinators and insectpollinated plants in Britain and the Netherlands. Science 313 (5785), 351-354.

Bommarco, R., Lundin, O., Smith, H.G., Rundlöf, M. (2012) Drastic historic shifts in bumble-bee community composition in Sweden. Proc. R. Soc. B 279 (1727), 309-315.

Borrell, B.J. (2005) Long Tongues and Loose Niches: Evolution of Euglossine Bees and Their Nectar Flowers 1. Biotropica: The Journal of Biology and Conservation 37:664-669.

Botsch, J.C., Walter, S.T., Karubian, J., González, N., Dobbs, E.K., Brosi, B.J. (2017) Impacts of forest fragmentation on orchid bee (Hymenoptera: Apidae: Euglossini) communities in the Chocó biodiversity hotspot of northwest Ecuador. J. Insect Conserv. 21 (4), 633-643.

Bretfeld M., Ewers B.E., Hall J.S. (2018) Plant water use responses along secondary forest succession during the 2015-2016 El Niño drought in Panama. New Phytologist 219:885-889.

Brown, M., Paxton, R. (2009) The conservation of bees: a global perspective. Apidologie 40 (3), 410-416.

Burkle, L.A., Marlin, J.C., Knight, T.M. (2013) Plantpollinator interactions over 120 years: loss of species, co-occurrence and function. Science 339 (6127), 1611-1615.

Colla, S.R., Packer, L. (2008) Evidence for decline in eastern North American bumblebees (Hymenoptera: Apidae), with special focus on Bombus affinis Cresson. Biodivers. Conserv. 17, 1379-1391.

Dressler, R.L. (1982) Biology of the orchid bees (Euglossini). Annu Rev Ecol Syst 13:373-394.

Eltz, T., Whitten W., Roubik D., Linsenmair K. (1999) Fragrance collection, storage, and accumulation by individual male orchid bees. J Chem Ecol 25:157-176.

Eltz, T., Sager A., Lunau K. (2005) Juggling with volatiles: exposure of perfumes by displaying male orchid bees. Journal of Comparative Physiology A 191:575-581.

Ferreira, M.G., Pinho, O.C., Balestieri, J.B.P., Faccenda, O. (2011) Fauna and stratification of male orchid bees (Hymenoptera: Apidae) and their preference for odor baits in a forest fragment. Neotrop. Entomol. 40 (6), 639-646.

Frankie, G.W., Thorp, R.W., Newstrom-Lloyd, L.E., Rizzardi, M.A., Barthell, J.F., Griswold, T.L., Kim, J.Y., Kappagoda, S. (1998) Monitoring Solitary Bees in Modified Wildland Habitats: Implications for Bee Ecology and Conservation. Environ. Entomol. 27 (5), 1137-1148.

Frankie, G., Rizzardi, M., Vinson, S., Griswold, T. (2009) Decline in bee diversity and abundance from 19722004 on a flowering leguminous tree, Andira inermis in Costa Rica at the interface of disturbed dry forest and the urban environment. J. Kansas Entomol. Soc. 82 (1), 1-21.

Fürst, M.A., McMahon, D.P., Osborne, J.L., Paxton, R.J., Brown, M.J.F. (2014) Disease associations between honeybees and bumblebees as a threat to wild pollinators. Nature 506, 364-366.

Giannini, T., Acosta, A., Garófalo, C., Saraiva, A., Alvesdos-santos, I., Imperatriz-Fonseca, V.L. (2012) Pollination services at risk: Bee habitats will decrease owing to climate change in Brazil. Ecol. Modell. 244, 127-131.

Goulson, D., Nicholls, E., Botías, C., Rotheray, E.L. (2015) Bee declines driven by combined stress from parasites, pesticides, and lack of flowers. Science 347 (6229), 1255957.

Grixti, J.C., Wong, L.T., Cameron, S.A., Favret, C. (2008) Decline of bumble bees (Bombus) in the North American Midwest. Biol. Conserv. 142 (1), 75-84.

Hallmann, C.A., Sorg, M., Jongejans, E., Siepel, H., Hofland, N., Sumser, H., Ho, T., Schwan, H., Stenmans, W., Mu, A., Goulson, D., de Kroon, H. (2017) More than 75 percent decline over 27 years in total flying insect biomass in protected areas. PLoS One 12 (10), e0185809.

Herrera, C. (2019) Complex long-term dynamics of pollinator abundance in undisturbed Mediterranean montane habitats over two decades. Ecol. Monogr. 89 (1), e01338.

Koh, I., Lonsdorf, E. V., Williams, N.M., Brittain, C., Isaacs, R., Gibbs, J., Ricketts, T.H. (2016) Modeling the status, trends, and impacts of wild bee abundance in the United States. Proc. Natl. Acad. Sci. U. S. A. 113 (1), 140-145.

Kosior, A., Celary, W., Olejniczak, P., Fijał, J., Król, W., Solarz, W., Płonka, P. (2007) The decline of the bumble bees and cuckoo bees (Hymenoptera: Apidae: Bombini) of Western and Central Europe. Oryx 41 (1), 79-88.

Laurance, W.F., Useche, D., Rendeiro, J., Kalka, M., Bradshaw, J., Sloan, S., Laurance, S., Campbell, M., Abernethy, K., Alvarez, P., ArroyoRodriguez, V., Ashton, P., Benítez-Malvido, J., Blom, A., Bobo, K., Cannon, C., Cao, M., Carroll, R., Chapman, C., Coates, R., Cords, M., Danielse, F., De Dijn, B., Dinerstein, E. (2012) Averting biodiversity collapse in tropical forest protected areas. Nature 489 (7415), 290-294.

López-Uribe, M., Oi, C., Del Lama, M. (2008) Nectarforaging behavior of Euglossine bees (Hymenoptera: Apidae) in urban areas. Apidologie 39 (4), 410-418.

Magurran AE. (2004) Measuring biological diversity. Oxford: Blackwell Publishing. 256 p.

Margatto, C., Berno, V.O., Gonçalves, R.B., Faria Jr., L.R.R. (2019) Orchid bees (Hymenoptera, Apidae, Euglossini) are seasonal in Seasonal Semideciduous Forest fragments, southern Brazil. Pap. Avulsos Zool. 59, e20195907. 
Martins, C.F., Souza, A.K.P. (2005) Estratificação vertical de abelhas Euglossina (Hymenoptera, Apidae) em uma área de Mata Atlântica, Paraíba, Brasil. Rev Bras Zool 22 (4), 913-918.

Meiners, J.M., Griswold, T.L., Carril, O.M. (2019) Decades of native bee biodiversity surveys at Pinnacles National Park highlight the importance of monitoring natural areas over time. PLoS ONE 14 (1), e0207566.

Miller-Struttmann, N.E., Geib, J.C., Franklin, J.D., Kevan, P.G., Holdo, R.M., Ebert-may, D., Lynn, A.M., Kettenbach, J.A., Hedrick, E., Galen, C. (2015) Functional mismatch in a bumble bee pollination mutualism under climate change. Nature 349 (6255), 1541-1544.

Nemésio, A. (2013) Are orchid bees at risk? First comparative survey suggests declining populations of forestdependent species. Brazilian J. Biol. 73 (2), 367-374.

Nemésio A, Rasmussen C (2011) Nomenclatural issues in the orchid bees (Hymenoptera: Apidae: Euglossina) and an updated catalogue. Zootaxa 3006:1-42.

Nemésio, A., Santos, L.M., Vasconcelos, H.L. (2015) Long-term ecology of orchid bees in an urban forest remnant. Apidologie 46 (3), 359-368.

Nemésio, A., Silva, D., Nabout, J., Varela, S. (2016) Effects of climate change and habitat loss on a forestdependent bee species in a tropical fragmented landscape. Insect Conserv. Divers. 9 (2), 149-160. https://doi.org/10.1111/icad.12154

Oliveira MLd, Campos Lucio Antonio de Oliveira (1995) Abundance, richness and diversity of Euglossinae bees (Hymenoptera, Apidae) in "Terra Firme" continuous forest in the Central Amazon, Brazil. Rev Bras Zool 12:547-556.

Ollerton, J. (2017) Pollinator Diversity: Distribution, Ecological Function, and Conservation. Annu. Rev. Ecol. Evol. Syst. 48 (1), 353-376.

Ollerton, J., Winfree, R., Tarrant, S. (2011) How many flowering plants are pollinated by animals? Oikos 120 (3), 321-326.

Ollerton, J., Erenler, H., Edwards, M., Crockett, R. (2014) Extinctions of aculeate pollinators in Britain and the role of large-scale agricultural changes. Science 346 (6215), 1360-1362.

Otero JP, Sallenave A. 2003. Vertical stratification of euglossine bees (Hymenoptera: Apidae) in an Amazonian forest. The Pan-pacific Entomologist, 31 Mar 2003, 79(2):151-154

Packer, L., Owen, R. (2001) Population genetic aspects of pollinator decline. Conserv. Ecol. 5 (1), 4.

Pearson, D., Dressler, R. (1985) Two-year study of male orchid bee (Hymenoptera: Apidae: Euglossini) attraction to chemical baits in lowland south-eastern Peru. J. Trop. Ecol. 1 (1), 37-54.

Pemberton, R.W., Wheeler, G.S. (2006) Orchid bees don't need orchids: evidence from the naturalization of an orchid bee in florida. Ecology 87 (8), 1995-2001.

Peruquetti RC, Campos LdO, Coelho CDP, Abrantes CVM, Lisboa LdO (1999) Abelhas Euglossini (Apidae) de áreas de Mata Atlântica: abundância, riqueza e aspectos biológicos. Rev Bras Zool 16:101118.

Potts, S., Biesmeijer, J., Kremen, C., Neumann, P., Schweiger, O., Kunin, W. (2010) Global pollinator declines: trends, impacts and drivers. Trends Ecol. Evol. 25 (6), 345-353.

Powell, A., Powell, G. (1987) Population dynamics of male euglossine bees in Amazonian forest fragments. Biotropica 19 (2), 176-179.

Pyke, G.H., Thomson, J.D., Inouye, D.W., Miller, T.J. (2016) Effects of climate change on phenologies and distributions of bumble bees and the plants they visit. Ecosphere 7 (3), e01267.

R Core Team (2019) R: A language and environment for statistical computing. R Foundation for Statistical Computing, Vienna, Austria. URL: https://www.Rproject.org/

Rada, S., Schweiger, O., Harpke, A., Kühn, E., Kuras, T., Settele, J., Musche, M. (2019) Protected areas do not mitigate biodiversity declines: A case study on butterflies. Divers. Distrib. 25 (2), 217-224.

Ramírez SR, Hernández C, Link A, López-Uribe MM (2015) Seasonal cycles, phylogenetic assembly, and functional diversity of orchid bee communities. Ecology and evolution 5:1896-1907.

Rocha-Filho, L., Garófalo, C. (2014) Phenological patterns and preferences for aromatic compounds by male euglossine bees (Hymenoptera, Apidae) in two coastal ecosystems of the Brazilian Atlantic Forest. Neotrop. Entomol. 43 (1), 9.

Roubik, D. (1993) Tropical pollinators in the canopy and understory: field data and theory for stratum "Preferences." J. Insect Behav. 6 (6), 659-673.

Roubik, D.W., 2001. Ups and downs in pollinator populations: when is there a decline? Conserv. Ecol. 5 (1), 2.

Roubik, D.W. (2004) Long-term studies of solitary bees: what the orchid bees are telling us. In: Solitary bees: Conservation, rearing, management for pollination, B. M. Freitas \& J. O. Pereira (eds), Imprensa Universitária, Fortaleza, pp. 97-103

Roubik, D.W., Ackerman, J.D. (1987) Long-term ecology of euglossine orchid-bees (Apidae: Euglossini) in Panama. Oecologia 73 (3), 321-333.

Roubik, D., Hanson, P., 2004. Orchid bees of tropical America: Biology and field guide. Instituto Nacional de Biodiversidad (INBio). Instituto Nacional de Biodiversidad (INBio), Heredia.

Roubik, D.W., Villanueva-Gutiérrez, R. (2009) Invasive Africanized honey bee impact on native solitary bees: A pollen resource and trap nest analysis. Biol. J. Linn. Soc. 98 (1), 152-160.

Roubik, D., Wolda, H. (2001) Do competing honey bees matter? dynamics and abundance of native bees before and after honey bee invasion. Popul. Ecol. 43 (1), 5362.

Sánchez-Bayo, F., Wyckhuys, K.A. G. (2019) Worldwide decline of the entomofauna: A review of its drivers. Biol. Conserv. 232 (April 2019), 8-27. 
Santos-Murgas, A., Abrego, J., López, O., Monteza, C., Osorio, M., Guardia, R., Álvarez, E., Quiroz, K., Añino, Y., Carranza, R., Villarreal, C. (2018) Abejas de las orquídeas (Hymenoptera: Apidae) del parque nacional Darién, Panamá. Tecnociencia 20 (2), 59-69.

Schulze, C.H., Linsenmair, K.E., Fiedler, K., 2001. Understorey versus canopy: patterns of vertical stratification and diversity. Plant Ecol. 153 (1-2), 133-152.

Senapathi, D., Carvalheiro, L., Biesmeijer, J., Dodson, C., Evans, R., McKerchar, M., Morton, R., Moss, E., Roberts, S., Kunin, W. (2015) The impact of over 80 years of land cover changes on bee and wasp pollinator communities in England. Proc. R. Soc. B Biol. Sci. 282 (1806), 20150294.

Shuttleworth, W., Gash, J., Lloy, C., Moore, C., Roberts, J. (1984) Daily variations of temperature and humidity within and above amazonian forest. Weather 40 (4), 102-108.

Soroye, P., Newbold, T., Kerr, J. (2020). Climate change contributes to widespread declines among bumble bees across continents. Science 367 (6478), 685-688.

Stangler, E.S., Hanson, P.E., Steffan-Dewenter, I. (2016) Vertical diversity patterns and biotic interactions of trap-nesting bees along a fragmentation gradient of small secondary rainforest remnants. Apidologie 47 (4), 527-538.

Storck-Tonon, D., Peres, C.A. (2017) Forest patch isolation drives local extinctions of Amazonian orchid bees in a
26 years old archipelago. Biol. Conserv. 214 (October 2017), 270-277.

UNESCO World Heritage. 1981. Darien National Park. https://whc.unesco.org/en/list/159.

Valtuille-Faleiro, F., Nemésio, A., Loyola, R. (2018) Climate change likely to reduce orchid bee abundance even in climatic suitable sites. Glob. Chang. Biol. 24 (6), 2272-2283.

Vilhena, P., Rocha, L., Garófalo, C. (2017) Male orchid bees (Hymenoptera: Apidae: Euglossini) in canopy and understory of Amazon Várzea floodplain forest. I. Microclimatic, seasonal and faunal aspects. Sociobiology 64 (2), 191-201.

Williams, N., Minckley, R., Silveira, F. (2001) Variation in native bee faunas and its implications for detecting community changes. Conserv. Ecol. 5 (1), 7.

Winfree, R., Aguilar, R., Vasquez, D., LeBuhn, G., Aizen, M. (2009) A meta-analysis of bees' responses to anthropogenic disturbance. Ecology 90 (8), 2068-2076.

Wright, S.J., Calderon, O., 1995. Phylogenetic patterns among tropical flowering phenologies. J. Ecol. 83 (6), 937-948.

Publisher's note Springer Nature remains neutral with regard to jurisdictional claims in published maps and institutional affiliations. 